\title{
Valorization of the Olive Oil Production Residue: Healthy Ingredient for Developing High Value-Added Spread
}

\author{
Varvara Andreou, Sofia Chanioti (D), Panagiota Stergiou and George Katsaros * D \\ Institute of Technology of Agricultural Products, Hellenic Agricultural Organization-DEMETER, \\ 14123 Lykovrissi, Greece; vandreou@chemeng.ntua.gr (V.A.); schanioti@gmail.com (S.C.); \\ ster.panagiota@gmail.com (P.S.) \\ * Correspondence: gkats@chemeng.ntua.gr; Tel.: +30-210-284-5940
}

check for

updates

Citation: Andreou, V.; Chanioti, S.; Stergiou, P.; Katsaros, G. Valorization of the Olive Oil Production Residue: Healthy Ingredient for Developing High Value-Added Spread. Sustainability 2021, 13, 13984. https:/ / doi.org/10.3390/su132413984

Academic Editors: Thrassyvoulos Manios, Katia Lasaridi, Ioannis N. Daliakopoulos and Christina Chroni

Received: 26 October 2021

Accepted: 16 December 2021

Published: 17 December 2021

Publisher's Note: MDPI stays neutral with regard to jurisdictional claims in published maps and institutional affiliations.

Copyright: (c) 2021 by the authors. Licensee MDPI, Basel, Switzerland. This article is an open access article distributed under the terms and conditions of the Creative Commons Attribution (CC BY) license (https:// creativecommons.org/licenses/by/ $4.0 /)$.

\begin{abstract}
This study focused on the development of a new olive-based product enriched with proteins, antioxidant compounds and functional properties, aiming at valorization of the olive residue from the typical olive oil extraction process. Olive oil was extracted using a patented cold pressing machine, resulting in a valuable source of bioactive compounds in the form of olive residue (pulp $\sim 70 \%$, pit- and skin-free). Conventional (solid: water ratio 1:4, $25^{\circ} \mathrm{C}, 2 \mathrm{~h}$ ) and $\mathrm{HP}$ assisted (200 MPa, solid:water ratio 1/4, $10 \mathrm{~min}$ ) de-bittering processes were carried out in order to remove oleuropein content (up to 50\%) from olive residue, thus decreasing its bitter taste. The olive spread was prepared with olive residue (50\%) and honey (25\%), enriched with proteins (24.5\%) from nuts. Quality parameters, nutritional attributes, microbiological analysis, phenolic compounds and oxidative stability as well as sensory evaluation of the olive spread were conducted during storage. Its shelf-life was estimated (prediction through accelerated tests) as 9.5 months when stored at $4{ }^{\circ} \mathrm{C}$. The organoleptic evaluation showed that the proposed olive spread had a texture similar to peanut butter and could potentially be consumed as a health-promoting spread due to its high content of proteins $(\sim 10 \mathrm{~g} / 100 \mathrm{~g})$, crude fibers ( $>6 \mathrm{~g} / 100 \mathrm{~g})$ and essential fatty acids.
\end{abstract}

Keywords: olive residue; spread; valorization; de-bittering; high pressure; phenolic content

\section{Introduction}

Olive oil production is an important Mediterranean agricultural activity, considered to be one of the major driving forces of the Greek economy [1]. More than $97 \%$ of global olive production is concentrated in the Mediterranean area [2,3], mainly in Spain, Italy, Greece, Turkey, Morocco and Tunisia [4]. Olive oil is typically produced by mechanical extraction [5]; the old-fashioned pressing process was replaced by the continuous centrifugation process, including a three-phase and later a two-phase system [6,7]. However, the production of olive oil is characterized by significant amounts of both solid and liquid residue [8]. Their management has become a challenge for the olive mill operators both from economic and environmental perspectives [9]. The solid residue derived from the two-phase olive oil extraction system constitutes a promising biomass resource [10]. It is rich in high added-value and antioxidant compounds [11], such as phenolic compounds, mainly hydroxytyrosol, tyrosol, caffeic acid, p-coumaric acid, rutin, quercetin, luteolin and apigenin [12]. Current research has already focused on its post-treatment approaches and valorization [13], such as the recovery of valuable natural components using organic solvents [14-16]. The extraction can be costly with low recovery yield, also causing significant environmental issues $[17,18]$. However, the valorization of olive oil residue as a source of ready-to eat-product has not been studied. This is mainly due to three factors: (i) it contains skin, pit and pulp fragments [19] that cannot be integrated as-is into novel functional foods; (ii) it is bitter due to the presence of oleuropein glucoside, the main phenolic compound [20,21]; (iii) it demands thorough washing of the fresh olive fruit so as to avoid the presence of pesticide residues in the final pulp. Therefore, a careful washing of the olives 
and a de-bittering step of the olive oil residue would be mandatory steps. De-bittering could be based on oleuropein removal, decreasing the characteristic bitter taste [22] and increasing consumer acceptability [23]. The conventional de-bittering technique has long processing times, resulting also in removal of several useful antioxidants and solutes [24].

The objectives of this study were: (a) the application of a patented cold pressing machine providing improved oil yields and quality characteristics, while simultaneously separating the pulp from olive pit and skin; (b) investigating the effect of an alternative technique, i.e. high pressure (HP) on accelerating the de-bittering process of olive oil residue [25] before its integration into a novel product by instant removal of oleuropein from the olive oil residue [26]; (c) the development of a new product with enhanced nutritional attributes and functional properties. The valorization of olive residue is also crucial regarding the environmental impact of olive oil production, since it will become more sustainable and efficient with reduced footprint. Within this work, we offer a thorough and detailed analysis of the results presented in RETASTE Conference 2021 [27].

\section{Materials and Methods}

\subsection{Raw Material}

The experiments were carried out using olives (Koroneiki cv.) cultivated in Crete, Greece. Olives were in the 2nd stage of ripening (green with black dots). After harvesting, half of them were treated for oil extraction using the patented HP semi-automatic hydraulic system, while for the other half, the oil was extracted conventionally, using the appropriate semi-lab-scale equipment of the Laboratory of Food Engineering of the Institute of Technology of Agricultural Products-ELGO-Demeter.

\subsection{Experimental Design}

The experimental set up is presented in Figure 1.

In the first step, olives were pressed using a patented cold pressing machine, resulting in a pit- and skin-free olive paste. The conventional de-oiling procedure of olive paste followed in order to receive the extra virgin olive oil trapped in the paste and the solid olive paste residue. Olive oil yield and olive paste residue were evaluated. During the second step, de-bittering of olive paste residue using a conventional technique and a technique assisted by HP was performed. Oleuropein content and total phenolic compounds were measured for both de-bittered olive paste residues. In the final step, the de-bittered olive paste residue was incorporated in a new olive-based functional product, aiming to enhance its nutritional and functional properties. Accelerated shelf-life evaluation was carried out, in terms of microbiological analysis, quality parameters, bioactive compounds and sensory characteristics.

\subsection{Olive Oil Cold Extraction}

Virgin olive oil was cold extracted using a patented cold pressing machine. A patented high-pressure semi-automatic hydraulic system, integrating the invented "Hydraulic Direct Cold Press Method" developed by PETROKOLYMPOS IKE could provide significantly higher yields and olive paste residue, separated from olive pit and skin (Patents No. 1008674 / 1009206 / 1009355 \& 1009545 from Hellenic Industrial Property Organization).

The resulting olive paste (pit- and skin-free) was malaxated for $45 \mathrm{~min}$ in metallic batch chambers inside a lab-scale malaxator with a thermostat standardized at $30^{\circ} \mathrm{C}$. These malaxation conditions were selected based on previous works cited in the literature [16,28]. The centrifugation step followed for the malaxated olive paste, at $2000 \mathrm{rpm}$ for $4 \mathrm{~min}$. The extracted olive oil was filtered to separate solids and stored until further analysis. The olive oil residue was also collected and stored under vacuum at $4{ }^{\circ} \mathrm{C}$, until the de-bittering process was conducted, in order to avoid any quality degradation. 


\section{Determination of Olive Oil Extraction Yield}

After the olive oil collection, the olive oil yield was calculated according to Equation (1):

$$
\text { Olive oil yield } \%=\frac{\mathrm{kg} \text { of olive oil }}{\mathrm{kg} \text { of olives }} \cdot 100
$$

For each treatment condition the olive oil yield was measured twice.
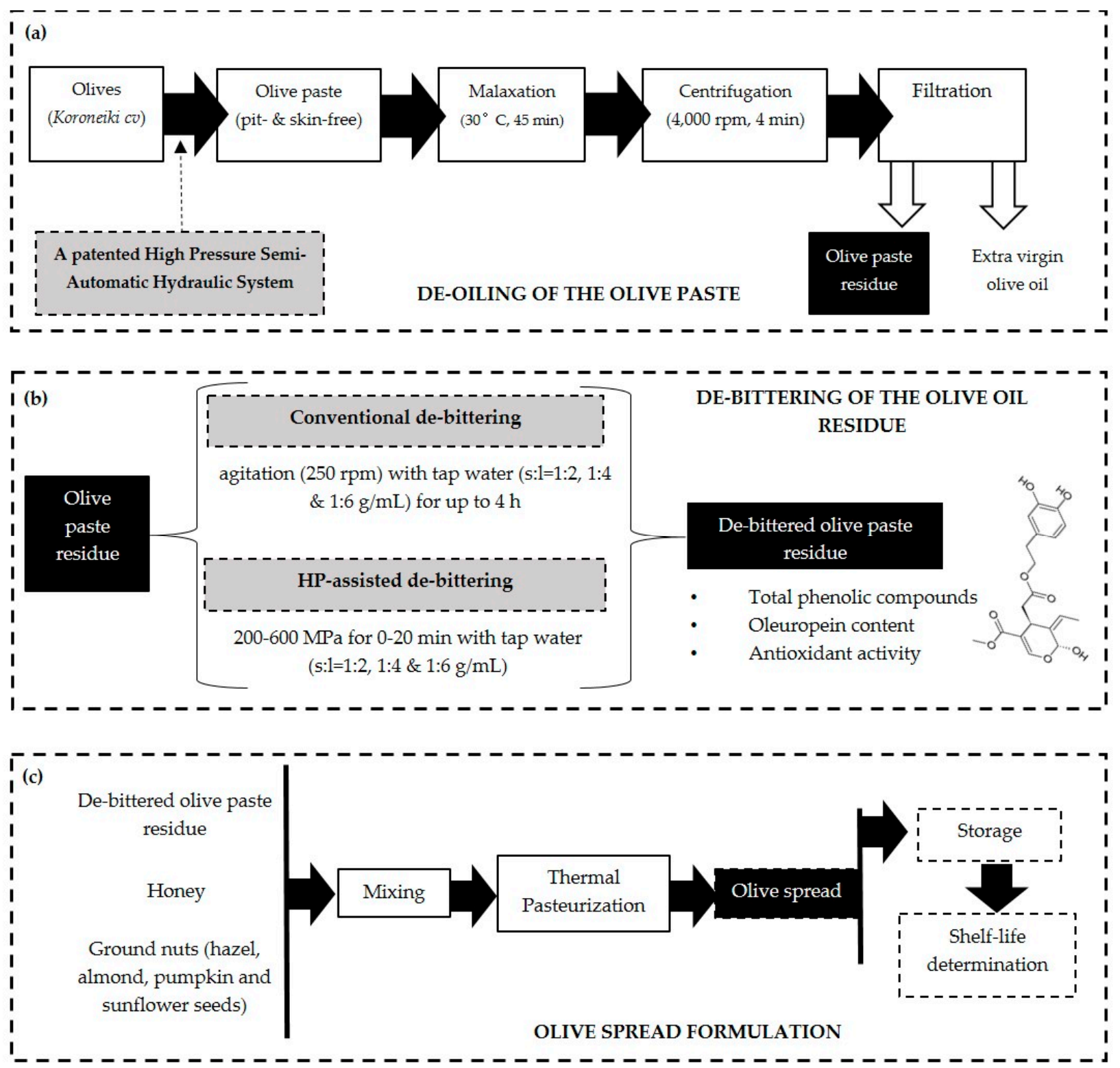

Figure 1. Schematic representation of (a) de-oiling of the olive paste, (b) conventional and HP-assisted de-bittering of the olive paste residue and (c) olive spread formulation flow chart.

\subsection{De-Bittering of Olive Oil Residue \\ 2.4.1. Conventional De-Bittering}

Conventional de-bittering method was performed at room temperature under agitation $(250 \mathrm{rpm}$ ) with tap water for $0-4 \mathrm{~h}$ in an ice-bath. The mass ratios studied of olive oil residue to tap water $\left(\mathrm{w}_{\text {solid }} / \mathrm{w}_{\text {water }}\right)$ were $1: 2,1: 4$ and $1: 6$. In the mixture, ascorbic acid $1 \%$ $\mathrm{w} / \mathrm{w}$ was added in order to avoid enzymatic browning during the process. The optimal 
de-bittering conditions were selected based on the decrease of the oleuropein content achieved in the shortest time possible.

\subsubsection{High-Pressure-Assisted De-Bittering}

The olive paste residue was also de-bittered by application of high-pressure technology (HP). HP unit (Food Pressure Unit FPU 1.01, Resato International BV, Roden, Holland) used for de-bittering of olive oil residue comprised a pressure intensifier and a vessel of 1.5 L capacity. A polyglycol class of viscosity ISO VG 15 (Resato International BV, Roden, Holland) was the pressure-transmitted fluid. Temperature and pressure inside the batch container were monitored every $3 \mathrm{~s}$ during the treatment. Olive paste residue $(\sim 200 \mathrm{~g})$ was mixed with tap water (solid:liquid mass ratios studied equal to 1:2, 1:4 and 1:6) and ascorbic acid $1 \% \mathrm{w} / \mathrm{w}$ and was packaged inside a multilayer PP aluminum material before $\mathrm{HP}$ treatment. De-bittering experiments were conducted at $25^{\circ} \mathrm{C}$ using 200 and $600 \mathrm{MPa}$ for 10 and $20 \mathrm{~min}$. The optimal HP conditions were selected based on the higher oleuropein content decrease and on the milder necessary conditions.

\subsection{New Product Formulation}

After the conventional and HP-assisted de-bittering process, the olive paste residue for each treatment was strained, filtered to remove the tap water and ground in order to obtain a homogenous starting material. It was analyzed and compared in terms of residual phenolic content, protein and fat content. Furthermore, both de-bittered olive paste residues were used independently to develop an innovative high-added-value healthy spread. Preliminary experiments were performed in order to select the optimal product formulation recipe, based on high sensory acceptability, superior quality and high nutritional enrichment. The optimal formulation of this new product included ground de-bittered olive residue (50\%) (obtained by conventional or HP-assisted de-bittering process) and honey $(25 \%)$, while it was also enriched with proteins $(24.5 \%)$ derived from ground nuts (hazel, almond, pumpkin and sunflower seeds). Citric acid (0.5\%) was also added to fix $\mathrm{pH}$ value below 4.50. The new healthy spread was packed in glass containers and was thermally pasteurized at $100{ }^{\circ} \mathrm{C}$ for $15 \mathrm{~min}$, assuring food safety and shelf-life extension.

\subsection{Quality Assessment and Microbiological Stability of the Olive Spread}

2.6.1. Physicochemical Parameters of the Olive Spread

Color measurements in CIELab colorscale (Commission International de l'Eclairage) of both olive oil spreads were measured using a colorimeter Minolta CR-300 (Minolta Company, Chuo-Ku, Osaka, Japan). Water activity $\left(\mathrm{a}_{\mathrm{W}}\right)$ of both samples was also determined using a Rotronic $\mathrm{a}_{\mathrm{w}}$-meter (HygroPalm, HP-23-AW-A, Bassersdorf, Switzerland). Moreover, the $\mathrm{pH}$ value of the samples was measured using an ORION pH meter (ORION 900 ion analyzer model 900 A, ORION-scientific, Boston, USA) with an ORION electrode (Orion Research electrode, model 950, 1996, Boston, USA). All measurements were repeated in triplicate.

\subsubsection{Texture Analysis of the OLIVE Spread}

The texture properties of the olive spreads were measured using a TA: HD plus texture analyzer (Stable Micro Systems Ltd., Godalming, UK). Glass containers were filled with the olive spreads $(\sim 30 \mathrm{~g})$. A steel cone was used for analysis of spreadability of the samples. The probe penetrated the sample at $10.0 \mathrm{~mm}$ depth with a $2.0 \mathrm{~mm} / \mathrm{s}$ velocity. The maximum peak force was expressed as firmness $(\mathrm{N})$. The area under the positive curve produced was determined as the work of penetration, corresponding to the energy required to deform the samples to the defined distance and is called spreadability ( $\mathrm{kg} \mathrm{s}$ ). The adhesiveness $(\mathrm{kg} \mathrm{s})$ was determined from the area under the negative curve. All measurements were repeated five times. 


\subsubsection{Nutritional Profile of the Olive Spread}

The major nutritional parameters of the olive oil spread that were evaluated were the moisture, ash, total proteins, fats and crude fiber content. Moisture content was determined by drying at $110{ }^{\circ} \mathrm{C}$ (Memmert, B50 type, Memmert $\mathrm{GmbH}+\mathrm{Co}$. KG) for $24 \mathrm{~h}$. Ash and crude fiber content were measured according to AOAC Official Method 923.03 and Weende method [29], respectively. Total protein content of all samples was determined according to Kjeldahl method (IDF, 2008) using a Kjeldahl rapid distillation unit (Protein Nitrogen Distiller DNP-1500-MP, RAYPA, Spain). The nitrogen-to-protein conversion factor for the Kjeldahl method was 6.25 [30]. For the determination of fat content, $5 \mathrm{~g}$ of the homogenized olive oil spreads was mixed in a pre-weighted dry Erlenmeyer flask with $25 \mathrm{~mL}$ petroleum ether. The mixture was stirred for $1 \mathrm{~h}$ and the supernatant was separated. The above procedure was repeated three times for each sample. Subsequently, the pooled supernatants (approximately $75 \mathrm{~mL}$ for each sample) were left overnight at room temperature to evaporate the solvent. The samples were dried in an oven at $100{ }^{\circ} \mathrm{C}$ for $1 \mathrm{~h}$ and the dry weight was measured [31]. The carbohydrate content was calculated by subtracting the other nutrition components $[16,32,33]$. All measurements were repeated in triplicate and expressed as g/100 g dry mass (d.m.) of product.

\subsubsection{Fatty Acids Profile}

Fatty acids profile of the olive spreads was performed using a methyl-ester analysis with gas chromatography according to AOAC official method 996.06 [34]. Fatty acid methyl esters (FAMEs) were prepared from the olive spreads by direct trans-esterification using $2 \%$ sulfuric acid in methanol [28]. Potassium hydroxide $(0.7 \mathrm{~mL})$ and $5.3 \mathrm{~mL}$ of methanol with $0.05 \%$ of butylated hydroxyl toluene (BHT) were added to the tube and incubated in a boiling water bath set at $55^{\circ} \mathrm{C}$ for $90 \mathrm{~min}$ with vigorous shaking of $20 \mathrm{~s}$ for every $20 \mathrm{~min}$. After incubation, the tubes were cooled under tap water followed by addition of $2 \%$ sulfuric acid and incubation at $55^{\circ} \mathrm{C}$ for $90 \mathrm{~min}$. The resulting methylesters of the fatty acids were measured inside a glass tube with a $2 \mathrm{~mm}$ diameter. The glass tubes were packaged with 5\% SP-2340 in Chromosorb WAW (100-120 grids). The analysis was performed using a GC analysis system (Hewlett-Packard 5880) with a flame ionization detector (FID). Nitrogen was used as a carrier with a flow rate of $28 \mathrm{~mL} \mathrm{~min}^{-1}$. The temperature at the point of the injection was $220^{\circ} \mathrm{C}$ and at the point of the detector was $300{ }^{\circ} \mathrm{C}$. The temperature inside the tube was increasing for $2 \mathrm{~min}$ until it reached $80^{\circ} \mathrm{C}$. Free fatty acids were quantified according to calibration curves performed for the following standards: myristic acid (C14:0), palmitic acid (C16:0), palmitoleic acid (C16:1, cis-9), stearic acid (C18:0), elaidic acid (C18:1, trans-9), oleic acid (C18:1, cis-9), linoleic acid (C18:2 cis-9,12), $\alpha$-linolenic acid (C18:3, cis-9,12,15), arachidic acid (C20:0), cis-11-eicosenoic acid (C20:1), cis-11,14-eicosadienoic acid (C20:2), behenic acid (C22:0) and lignoceric acid (C24:0), all procured from Sigma-Aldrich (St. Louis, MO, USA).

\subsubsection{Bioactive Compounds of the Olive Spread}

The antioxidant potential including the total phenolic compounds and antioxidant activity of the olive spread was determined. The extraction of olive oil spread was carried out with a liquid-to-solid ratio (10:1) at $30^{\circ} \mathrm{C}$ according to Andreou et al. [16]. Ten grams of sample was mixed with $50 \%$ ethanol solution and agitated for $1 \mathrm{~h}$. The samples were centrifuged at $8000 \mathrm{rpm}$ for $15 \mathrm{~min}$ and the obtained extracts were filtered through $0.45 \mu \mathrm{m}$ filters. The total phenolic compounds were assessed using the Folin-Ciocalteu phenol reagent method [35]. The concentration in total phenolic compounds was expressed in $\mathrm{mg}$ caffeic acid equivalents per $100 \mathrm{~g}$ dry mass (mg CAE/100 g d.m.). Antioxidant capacity of the extracts was determined according to the method described by Brand-Williams, Cuvelier \& Berset [36] and was expressed as mg Trolox Equivalent/ $100 \mathrm{~g}$ d.m. DPPH reagent $(3.9 \mathrm{~mL})$ mixed with $100 \mu \mathrm{L}$ extract $\left(1: 10\right.$ dilution) and incubated at $25^{\circ} \mathrm{C}$ for $20 \mathrm{~min}$. More than $80 \%$ of total DPPH discoloration was achieved within the first 20 min of the reaction. For this reason, the absorbance was measured at $20 \mathrm{~min}$ at $595 \mathrm{~nm}$. The DPPH 
reagent was produced by mixing $2.5 \mathrm{mg}$ of solid DPPH with $100 \mathrm{~mL}$ methanol. All above measurements were performed twice and the standard deviations were also calculated.

\subsubsection{Microbiological Analysis}

Microbiological growth in terms of total aerobic bacteria (Plate Count Agar-Biokar Diagnostics, Beauvais, France) and the molds/yeasts (Rose-Bengal Chloramphenicol AgarBiokar Diagnostics, Beauvais, France) was also tested using the surface plating technique (ISO4833-2:2013). The incubation of the total viable count, yeasts and molds was performed under aerobic conditions at $30^{\circ} \mathrm{C}$ for $48 \mathrm{~h}$ and $25^{\circ} \mathrm{C}$ for $72 \mathrm{~h}$, respectively.

\subsubsection{Determination of Peroxide Value (PV)}

Peroxide value $(\mathrm{PV})\left(\mathrm{meqO} \mathrm{O}_{2} / \mathrm{kg}\right)$ of the extracted oil from olive spreads during shelf-life was determined according to the analytical method described in the Regulation EEC/2568/91 of the European Union Commission. The oil ( $1 \mathrm{~g})$ was extracted from olive spreads as described in Section 2.6.4. All above measurements were performed in triplicate and the standard deviations were also calculated.

\subsubsection{Sensory Evaluation}

Eight trained and certified panelists (including individuals of both sexes and different ages) scored the main sensory attributes of the new healthy olive spreads. The sensory evaluation of samples was carried out in an accredited laboratory for sensory evaluation of foods in the Institute of Technology of Agricultural Products of ELGO-DEMETER in a very specific tasting space with controlled conditions in order to reduce the external influences for the panelists. Each panelist performed an individual blind trial of each sample and scored all organoleptic characteristics using a hedonic scale which ranged from 1 to 9 to measure likeness and acceptability of the samples. Each sample ( 20 g) was offered in a glass container $(7 \mathrm{~mm}$ diameter) at room temperature. The mean values were calculated for every characteristic, such as appearance, fresh-like aroma, flavor, taste, aftertaste and overall acceptability. This procedure is widely used in the literature for new food products [37-40]. It is a research tool that offers means of determining whether product differences are perceived and whether one product is liked more than another.

\subsection{Accelerated Shelf-Life Determination}

The new healthy spread was packed in glass containers and was thermally pasteurized at $100{ }^{\circ} \mathrm{C}$ for $15 \mathrm{~min}$ to assure food safety and shelf-life extension. Then, the samples were stored in high-precision incubators (Friocell 222-ECO line, MMM Group, Medcenter Einrichtungen $\mathrm{GmbH}$ ) at temperatures 20,30 and $40{ }^{\circ} \mathrm{C}$ under darkness, for $\sim 6$ months. Based on quality deterioration (color, $\mathrm{pH}$, oxidative stability and sensory evaluation), the shelf-life of the new product was predicted.

\subsection{Data Analysis}

Mathematical Modelling of the Shelf-Life Determination of the Olive Spreads

Peroxide value during storage at all studied temperatures was modelled through apparent first-order kinetics, as described by Equation (2) [41] and the shelf-life determination of both de-bittered olive spreads was calculated based on Equation (3) [42]:

$$
\begin{gathered}
\mathrm{PV}=\mathrm{PV}_{0}+\mathrm{k} \cdot \mathrm{t} \\
\mathrm{t}_{\mathrm{SL}}=\frac{\mathrm{PV}_{\text {limit }}-\mathrm{PV}_{0}}{\mathrm{k}}
\end{gathered}
$$

where $\mathrm{PV}$ and $\mathrm{PV}_{0}$ are the peroxide value at time $t$ and zero time, $\mathrm{PV}_{\text {limit }}\left(=30\right.$ meqO $\left.\mathrm{O}_{2} / \mathrm{kg}\right)$ is the peroxide value that was set as the limit value for minimum acceptability, indicating the initial stage of fat and oil deterioration in foods according to literature [43], $\mathrm{k}$ the rate constant of the PV value increase during storage $\left(\mathrm{d}^{-1}\right)$ and $\mathrm{t}$ the storage time $(\mathrm{d})$. 


\subsection{Statistical Analysis}

A one-way analysis of variance (ANOVA) was used to evaluate the statistically significant differences and the interaction between the obtained parameters of olive spreads and the de-bittering methods. The experimental data were analyzed using Statistica 7 (Stat Soft, Tulsa, OK, USA). The comparisons of means were calculated using Duncan's test at the $5 \%$ level of significance $(p \leq 0.05)$. F-value, degree of freedom (df) and the level of significance were calculated for all studied conditions and treatments.

\section{Results and Discussion}

\subsection{Olive Oil Production}

Olive oil production was performed using the patented cold pressing machine instead of the traditional grinding step in order to obtain the olive paste. By the use of this machine the olive fruits were pressed, achieving a homogeneous olive paste that contains only olive flesh, while the pits, residual leaves and olive skin were removed. Olive oil yield from cold-pressed olives was determined to be equal to $22.19 \pm 0.3 \%$. This number is in accordance with the results of Andreou et al. [28] that obtained a yield for Tsounati variety (Crete, Greece) olives equal to $21.9 \%$ having been malaxated at $30^{\circ} \mathrm{C}$ for $30 \mathrm{~min}$. Similarly, Inarejos-García, Gómez-Rico, Salvador \& Fregapane [44] reported a yield value equal to $20.6 \%$ for Cornicabra variety olives after malaxation at $28^{\circ} \mathrm{C}$ for $60 \mathrm{~min}$.

No significant differences were observed compared to the conventional olive oil procedure with the grinding step that offered a $21.37 \pm 0.4 \%$ yield. The patented cold pressing machine was optimized and yielded $70 \%$, meaning that $1 \mathrm{~kg}$ of olives resulted in $0.7 \mathrm{~kg}$ of olive paste. The total olive oil yield (yield from the cold pressing of olives followed by typical olive oil extraction) was estimated to be equal to $15.0 \pm 0.3 \%$, leading to a $32 \%$ decrease compared to traditional olive oil production.

In general, crushing of olives using different techniques, such as the traditional stone mill, the hammer or disk-crushing machine or the de-stoner, strongly affects the oil yield and quality, as reported by several researchers [45-48]. Di Giovacchino et al. [49] and Catalano \& Caponio [50] observed that olive oils extracted from olive paste that had been prepared by hammer crushers had higher yield $(p<0.05)$ and resulted in higher phenolic content $(p<0.05)$ compared to the traditional stone mill. Caponio \& Catalano [51] confirmed that disk-crushed olives led to higher olive oil yield compared to hammer-crushed ones as a result of the emulsion formation that impeded the easy oil separation. In agreement with our study, Amirante, Clodoveo, Tamborrino, Leone \& Paice [52] showed that the oil extracted from de-stoned pastes had slightly decreased $(p>0.05)$ yield compared to the traditional crushing method and high nutritional quality, as well as high yield of olive pomace rich in monounsaturated fatty acids.

The olive paste residue resulting from the oil separation after the centrifugation step had a residual oil content of approximately $0.7 \mathrm{~g}$ oil $/ \mathrm{g} \mathrm{d}$.m. and a high phenolic content equal to $18.45 \mathrm{mg} \mathrm{CAE} / \mathrm{g} \mathrm{d.m.,} \mathrm{making} \mathrm{it} \mathrm{suitable} \mathrm{for} \mathrm{reuse} \mathrm{and} \mathrm{incorporation} \mathrm{in} \mathrm{a} \mathrm{new}$ product, since all unsuitable substances, such as pits, residual leaves and olive skin, had already been removed from the cold press machine. In the traditional extraction process, the resulting olive oil residue was unsuitable for further reuse in food systems.

\subsection{Composition of Olive Paste Residue}

Olive residue (approximately 70\%, pit and skin-free) was used for the innovative food product development. The composition of the olive oil residue contains several valuable compounds, such as a high amount of phenolic compounds $(29.72 \mathrm{mg} / \mathrm{g} \mathrm{d}$.m.), a significant amount of carbohydrates, mainly crude fibers ( $30.53 \mathrm{~g} / 100 \mathrm{~g}$ d.m.), proteins (10.01 g/100 g d.m.), while its moisture and ash content were measured equal to $72.12 \%$ and $3.18 \%$, respectively. There is also a high amount of fat content $(33.5 \mathrm{~g} / 100 \mathrm{~g} \mathrm{d.m}$.), due to the remaining oil from the olive oil production. Other related studies $[16,53,54]$ evaluated the composition of olive residues and report significant differences among them, 
mainly attributed to different variety of initial olive fruit, to the stage of ripening and to the procedure followed for olive oil production.

\subsection{De-Bittering Process of Olive Residue}

The natural bitterness of the olive residue should be eliminated-or at least significantly reduced-by applying a de-bittering process, thus making it acceptable for human consumption. HP-assisted and conventional de-bittering kinetic experiments were conducted at predefined times and it was determined that the effect of each de-bittering method on oleuropein content and bitterness of the olive paste residue was crucial. Both de-bittering processes were carried out at three different solid:liquid ratios (1:2, 1:4 and $1: 6 \mathrm{~g} / \mathrm{mL}$ ) under agitation at room temperature. Total phenolic compounds of untreated, conventionally treated and HP-assisted de-bittered olive paste residues are presented in Figure 2. The significance of different terms of each treatment was determined using the F-value and $p$-value. The F-values of ANOVA for 1:2, 1:4 and 1:6 ratio were 24.41, 36.71 and 57.71 , respectively, with low probability value $(p<0.0001)$ implying that the different means between treatments were significant.

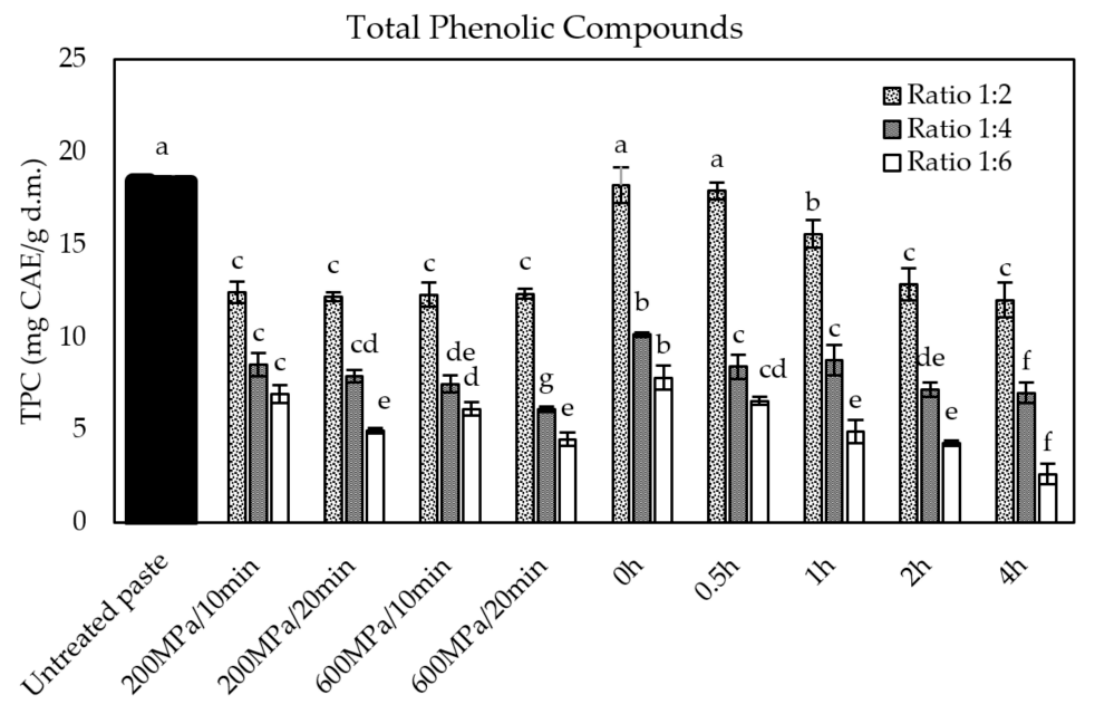

Figure 2. Total phenolic compounds of untreated, conventionally treated (for $0-4 \mathrm{~h}$ under agitation) and HP-assisted (200 and $600 \mathrm{MPa}$ for 10 and $20 \mathrm{~min}$ ) de-bittered olive paste residues at 1:2, 1:4 and 1:6 solid-liquid ratios. Error bars represent standard deviation from three replications of treatments. Different superscript small letters indicate significantly different means between HP-assisted and conventionally de-bittered olive paste residues at each solid:liquid ratio, according to Duncan's test $(p<0.05)$. F-values of ANOVA for 1:2, $1: 4$ and 1:6 ratio were $24.41^{* * *}, 36.71^{* * *}$ and $57.71^{* * *}$, respectively. df: 9 . Significance level: ${ }^{* *}: p<0.001$.

In general, HP led to de-bittered olive paste residue in a shorter time, compared to the conventional de-bittering technique. Total phenolic compounds in HP de-bittered olive paste were decreased by up to $75.7 \%$ compared to the untreated olive paste $(18.45 \mathrm{mg}$ $\mathrm{CAE} / \mathrm{g}$ d.m.), depending on the process conditions applied. Increase of the solid-liquid ratio or treatment time of conventional de-bittering procedure led to faster de-bittering. Total phenolic compounds of HP-assisted de-bittered samples had no significant differences between the different HP conditions applied at various intensities. However, application of $\mathrm{HP}$ as a de-bittering technique (even at mild process conditions) resulted in total phenolic content reduction equal to the one achieved from at least post $2 \mathrm{~h}$ processing with the conventional de-bittering technique at all studied liquid-solid ratios. Antioxidant activity of all samples was correlated to the concentration of total phenolic compounds. The maximum reduction in oleuropein content combined with the minimum needed time and the minimum needed water were the main factors for the selection of the ratio of sample 
per solution during de-bittering. The optimal ratio of sample per solution during both de-bittering techniques was 1:4, where the phenolic content of de-bittered samples was reduced significantly by up to $44 \%$ compared to the de-bittered samples with 1:2 ratio. Slight differences in phenolic content were observed between 1:4 and 1:6 ratio of sample per solution during de-bittering.

Oleuropein content and sensory evaluation in terms of bitterness of both samples at $1 / 4$ ratio of sample per solution were also evaluated (Table 1).

Table 1. Oleuropein content (mg/100 g d.m.) and bitterness intensity (score 1-9) of the untreated, conventionally treated ( $1 \mathrm{~h}$ under agitation) and HP-assisted (200 and $600 \mathrm{MPa}$ for 10 and $20 \mathrm{~min}$ ) de-bittered olive paste residues at $1 / 4$ ratio of sample per solution.

\begin{tabular}{|c|c|c|c|}
\hline & & $\begin{array}{l}\text { Oleuropein Content } \\
\text { (mg/g d.m.) }\end{array}$ & $\begin{array}{l}\text { Bitterness Intensity } \\
(9 \text { is the Max) }\end{array}$ \\
\hline \multicolumn{2}{|c|}{ Untreated paste } & $2.14 \pm 0.22^{a}$ & $8.9 \pm 0.1^{a}$ \\
\hline \multirow{4}{*}{$\begin{array}{l}\text { HP-assisted } \\
\text { de-bittering }\end{array}$} & $200 \mathrm{MPa} / 10 \mathrm{~min}$ & $1.09 \pm 0.06^{\mathrm{c}}$ & $6.5 \pm 0.2^{c}$ \\
\hline & $200 \mathrm{MPa} / 20 \mathrm{~min}$ & $0.96 \pm 0.03^{\mathrm{cd}}$ & $6.4 \pm 0.2^{c}$ \\
\hline & $600 \mathrm{MPa} / 10 \mathrm{~min}$ & $0.95 \pm 0.09^{\mathrm{cd}}$ & $6.6 \pm 0.1^{\mathrm{c}}$ \\
\hline & $600 \mathrm{MPa} / 20 \mathrm{~min}$ & $0.78 \pm 0.06^{\mathrm{d}}$ & $5.5 \pm 0.3^{\mathrm{d}}$ \\
\hline \multirow{2}{*}{$\begin{array}{c}\text { Conventional } \\
\text { de-bittering } \\
\text { F-value }\end{array}$} & $1 \mathrm{~h}$ & $1.55 \pm 0.22^{b}$ & $7.0 \pm 0.1^{b}$ \\
\hline & & $41.5^{* * *}$ & $116.6^{* * *}$ \\
\hline
\end{tabular}

\pm represents standard deviation from three replications of treatments. Different superscript small letters indicate significantly different means between untreated, HP-assisted and conventionally de-bittered olive paste residues, according to Duncan's test $(p<0.05)$. df: 9. Significance level: ${ }^{* * *}: p<0.001$.

Oleuropein content was decreased by up to $30 \%$ after $1 \mathrm{~h}$ conventional de-bittering. On the other hand, HP-assisted treatment for only 10 min resulted in $50 \%$ decrease of oleuropein content compared to the concentration of untreated paste $(2.14 \mathrm{mg} / 100 \mathrm{~g} \mathrm{d.m}$.). HP treatment significantly affected the intensity of the bitter taste of olive paste; this result was reflected by the scoring of HP de-bittered samples (score equal to 5.5-6.5 for bitter taste intensity). By contrast, the untreated and the conventionally de-bittered olive paste after $1 \mathrm{~h}$ treatment were scored with 8.9 and 7.0, respectively (in a 9-grade intensity hedonic scale). The F-values of ANOVA for oleuropein content and bitterness intensity were 41.5 and 116.6, respectively, with low probability value $(p<0.0001)$ implying that the different means between treatments were significant.

The selection of the optimal conditions for both de-bittering processes (conventional and HP-assisted) was based on a combination of higher oleuropein content reduction (more than $50 \%$ compared to untreated), reflecting the lower intensity of bitter taste and the most minimum processing time possible. A ratio of sample per solution 1:4 and de-bittering time $2 \mathrm{~h}$ and $10 \mathrm{~min}$ were selected as the optimal conditions for conventional and HP-assisted (200 MPa) de-bittering processes, respectively. Under these conditions, both de-bittered olive paste residues exhibited adequate oleuropein content reduction by up to $50 \%$.

The de-bittering process of olive fruits is a well-addressed procedure in literature, using different techniques. The most known de-bittering process of olives used industrially is the treatment with sodium hydroxide $(\mathrm{NaOH})$ [55-57]. Other researchers have reported different novel technologies as pretreatments in order to accelerate the time-consuming de-bittering process. Habibi et al. [58] observed that the ultrasound-assisted ( $35 \mathrm{kHz}$ and $40 \mathrm{~W}, 20 \mathrm{~min})$ de-bittering of olives with $\mathrm{NaOH}(2.0 \% \mathrm{NaOH})$ decreased the processing time by up to $48 \%$ in comparison with the conventional method. The same authors confirmed that the sonication of olives minimized de-bittering time and reduced the demands in $\mathrm{NaOH}$ concentration, working towards a $\mathrm{NaOH}$-free de-bittering process [59] that is a necessity for the relevant industry. Tamer et al. [23] proved that the use of $\mathrm{NaOH}(1.5 \%)$ combined with $\mathrm{NaCl}(3 \%)$ under vacuum impregnation (68 $\mathrm{kPa}$ ) decreased the de-bittering period to $6 \mathrm{~h}$, while the respective de-bittering technique under atmospheric pressure lasted $48 \mathrm{~h}$. The amount of total phenolic compounds also decreased by $21.43 \%$ compared 
to the de-bittering technique under atmospheric pressure. Garcia et al. [60] confirmed that olives could also lose their bitter taste due to the enzymatic oxidation of their phenolic compounds. The application of starter cultures such as a strain of Lactobacillus pentosus was selected by Servili et al. [61] to ferment Leccino cv. olives, speeding up fruit de-bittering, thus preventing deterioration and improving their sensory characteristics.

The nutritional characteristics, such as total fat, proteins, carbohydrates and moisture content of the untreated and both de-bittered olive paste residues are presented in Table 2 and are expressed as $\mathrm{g} / 100 \mathrm{~g}$ dry mass (d.m.).

Table 2. Nutritional characteristics, such as total fat, proteins, carbohydrates, moisture content and antioxidant capacity of the untreated and conventionally treated ( $2 \mathrm{~h}$ under agitation) and HP-assisted ( 200 for $10 \mathrm{~min}$ ) de-bittered olive paste residues at $1 / 4$ ratio of sample per solution.

\begin{tabular}{|c|c|c|c|c|}
\hline $\begin{array}{l}\text { Nutritional and Bioactive } \\
\text { Compounds }\end{array}$ & $\begin{array}{l}\text { Untreated Olive } \\
\text { Paste Residue }\end{array}$ & $\begin{array}{c}\text { HP-Assisted } \\
\text { De-bittered Olive } \\
\text { Paste Residue }\end{array}$ & $\begin{array}{l}\text { Conventionally } \\
\text { de-Bittered Olive } \\
\text { Paste Residue }\end{array}$ & F-Value \\
\hline $\begin{array}{c}\text { Moisture } \\
\left(\mathrm{g} \mathrm{H}_{2} \mathrm{O} / 100 \mathrm{~g} \text { fresh product }\right)\end{array}$ & $72.12 \pm 0.65^{b}$ & $85.57 \pm 1.20^{a}$ & $86.79 \pm 1.55^{a}$ & $139.84^{* * *}$ \\
\hline $\begin{array}{c}\text { Ash } \\
(\mathrm{g} / 100 \mathrm{~g} \text { d.m })\end{array}$ & $11.43 \pm 0.15^{\mathrm{a}}$ & $1.62 \pm 0.04^{b}$ & $1.75 \pm 0.12^{b}$ & $7400^{* * *}$ \\
\hline $\begin{array}{l}\text { Proteins } \\
\text { (g/100 g d.m) }\end{array}$ & $10.01 \pm 1.22$ & $10.59 \pm 1.01^{\mathrm{a}}$ & $10.20 \pm 0.83^{a}$ & $0.24^{\mathrm{ns}}$ \\
\hline $\begin{array}{l}\text { Total fat } \\
\text { (g/100 g d.m })\end{array}$ & $33.58 \pm 1.05^{\mathrm{a}}$ & $34.32 \pm 0.99^{\mathrm{a}}$ & $34.57 \pm 0.78^{a}$ & $1.45^{\mathrm{ns}}$ \\
\hline $\begin{array}{l}\text { Total carbohydrates } \\
\quad(\mathrm{g} / 100 \mathrm{~g} \text { d.m })\end{array}$ & $14.45 \pm 2.12^{a}$ & $14.51 \pm 1.45^{\mathrm{a}}$ & $15.98 \pm 1.01^{\mathrm{a}}$ & $0.83^{\mathrm{ns}}$ \\
\hline $\begin{array}{l}\text { Crude fibers } \\
\text { (g/100 g d.m })\end{array}$ & $30.53 \pm 2.12^{b}$ & $38.96 \pm 1.15^{\mathrm{a}}$ & $37.50 \pm 0.85^{\mathrm{a}}$ & $27.93^{* * *}$ \\
\hline $\begin{array}{l}\text { Antioxidant capacity } \\
\text { (mg Trolox/100 g d.m.) }\end{array}$ & $40.41 \pm 1.65^{a}$ & $20.81 \pm 1.05^{b}$ & $17.98 \pm 1.22^{\mathrm{c}}$ & $252.74^{* * *}$ \\
\hline
\end{tabular}

\pm represents standard deviation from three replications of treatments. Different superscript small letters indicate significantly different means between untreated, HP-assisted and conventionally de-bittered olive paste residues, according to Duncan's test $(p<0.05)$. df: 3 , significance levels: ${ }^{* *}: p<0.001$; ns: not significant $(p>0.05)$.

In general, HP had no effect on quality indices compared to conventional de-bittering. It was observed that both de-bittering processes affected the moisture, the protein and the total carbohydrates content of the olive paste residue. The antioxidant capacity of HPassisted and conventionally de-bittered olive paste residue was lower by approximately $50 \%$ and $60 \%$ compared to the untreated olive paste residue, as a result of total phenolic compounds extraction during the de-bittering step.

\subsection{Quality Characteristics of OLIVE Spread}

After the conventional and HP-assisted de-bittering process, the olive paste residue for each process was incorporated in an innovative, high-added-value, healthy olive-based spread. In Table 3 , the physicochemical parameters, such as $\mathrm{pH}$ value, water activity $\mathrm{a}_{\mathrm{w}}$ and color $\left(\mathrm{L}^{*}, \mathrm{a}^{*}, \mathrm{~b}^{*}\right)$ of the olive spreads produced by HP-assisted and conventionally de-bittered olive paste residue are depicted. No differences were observed in texture properties, such as firmness (8.38-9.12 N), spreadability (1.19-1.45 kg s) and adhesiveness $(0.42-0.65 \mathrm{~kg} \mathrm{~s})$ for both olive spreads. In general, the results showed that the proposed olive spread product had a texture similar to peanut butter. According to Muego, Resurreccion \& Hung [62], the firmness and adhesiveness of peanut butters ranged from 6.29 to $14.36 \mathrm{~N}$ and from 1.17 to $1.86 \mathrm{~kg} \mathrm{~s}$, respectively. Our texture analysis results are in accordance with Ahmed and Ali [63], who reported that the spreadability values of peanut butter samples prepared with different oil and peanut seed contents ranged from 1.55 to $9.12 \mathrm{~kg} \mathrm{~s}$. 
Table 3. Physicochemical parameters, such as $\mathrm{pH}$ value, water activity aw and color $\left(\mathrm{L}^{*}, \mathrm{a}^{*}, \mathrm{~b}^{*}\right)$ of spreads produced from $\mathrm{HP}$-assisted (200 MPa, $10 \mathrm{~min}, 1: 4$ ratio of sample per solution) and conventionally (2 h, 1:4 ratio of sample per solution) de-bittered residues.

\begin{tabular}{cccc}
\hline Quality Parameters & $\begin{array}{c}\text { Spread Produced by HP-Assisted } \\
\text { de-Bittered Olive Residue }\end{array}$ & $\begin{array}{c}\text { Spread Produced by Conventionally } \\
\text { de-Bittered Olive Residue }\end{array}$ & F-Value \\
\hline $\mathrm{pH}$ & $4.22 \pm 0.01^{\mathrm{a}}$ & $4.23 \pm 0.01^{\mathrm{a}}$ & $5.00^{\mathrm{ns}}$ \\
$\mathrm{a}_{\mathrm{W}}$ & $0.936 \pm 0.004^{\mathrm{a}}$ & $0.941 \pm 0.010^{\mathrm{a}}$ & $3.80^{\mathrm{ns}}$ \\
Moisture $\left(\mathrm{g} \mathrm{H} \mathrm{H}_{2} \mathrm{O} / 100 \mathrm{~g}\right)$ & $47.98 \pm 2.84^{\mathrm{a}}$ & $49.15 \pm 1.04^{\mathrm{a}}$ & $0.30^{\mathrm{ns}}$ \\
Ash (g/100 g) & $0.88 \pm 0.03^{\mathrm{b}}$ & $0.93 \pm 0.04^{\mathrm{a}}$ & $10.24^{\mathrm{ns}}$ \\
$\mathrm{L}^{*}$ & $47.79 \pm 0.39^{\mathrm{b}}$ & $49.59 \pm 0.67^{\mathrm{a}}$ & $53.70^{* *}$ \\
$\mathrm{a}^{*}$ & $0.63 \pm 0.14^{\mathrm{a}}$ & $0.78 \pm 0.11^{\mathrm{a}}$ & $5.56^{\mathrm{ns}}$ \\
$\mathrm{b}^{*}$ & $21.33 \pm 0.51^{\mathrm{a}}$ & $18.74 \pm 0.36^{\mathrm{b}}$ & $160.96^{* * *}$ \\
Firmness (N) & $8.38 \pm 1.69^{\mathrm{a}}$ & $9.12 \pm 0.89^{\mathrm{a}}$ & $0.45^{\mathrm{ns}}$ \\
Spreadability (kg s) & $1.19 \pm 0.34^{\mathrm{a}}$ & $1.45 \pm 0.21^{\mathrm{a}}$ & $1.26^{\mathrm{ns}}$ \\
Adhesiveness (kg s) & $0.42 \pm 0.09^{\mathrm{a}}$ & $0.65 \pm 0.15^{\mathrm{a}}$ & $5.18^{\mathrm{ns}}$ \\
\hline
\end{tabular}

\pm represents standard deviation from three replications of treatments. Different superscript small letters indicate significantly different means between HP-assisted and conventionally de-bittered olive spreads, according to Duncan's test $(p<0.05)$. df: 1 , significance levels: ${ }^{* * *}: p<0.001 ; * *: p<0.01$; ns: not significant $(p>0.05)$.

The application of different de-bittering processes did not significantly affect the physicochemical parameters of the olive spreads. Table 4 presents the nutritional characteristics and bioactive compounds of olive spreads produced by HP-assisted and conventionally de-bittered olive paste residue.

Table 4. Nutritional parameters of spreads produced from HP-assisted (200 MPa, $10 \mathrm{~min}, 1: 4$ ratio of sample per solution) and conventionally ( $2 \mathrm{~h}, 1: 4$ ratio of sample per solution) de-bittered residues.

\begin{tabular}{|c|c|c|c|}
\hline Nutritional Parameters & $\begin{array}{c}\text { Spread Produced by HP-Assisted } \\
\text { de-Bittered Olive Residue }\end{array}$ & $\begin{array}{l}\text { Spread Produced by Conventionally } \\
\text { de-Bittered Olive Residue }\end{array}$ & F-Value \\
\hline Total Fat (g/100 g) & $17.88 \pm 1.22^{\mathrm{a}}$ & $16.48 \pm 1.15^{\mathrm{a}}$ & $2.09 \mathrm{~ns}$ \\
\hline Proteins (g/100 g) & $8.57 \pm 0.82^{\mathrm{a}}$ & $9.42 \pm 0.95^{\mathrm{a}}$ & $1.37^{\mathrm{ns}}$ \\
\hline Total Carbohydrates (g/100 g) & $17.72 \pm 0.15^{\mathrm{a}}$ & $16.25 \pm 0.88^{b}$ & $9.45^{\mathrm{ns}}$ \\
\hline Sugars $(g / 100 \mathrm{~g})$ & $1.43 \pm 0.12^{\mathrm{a}}$ & $1.25 \pm 0.06^{\mathrm{a}}$ & $5.40^{\mathrm{ns}}$ \\
\hline Crude fibers (g/100 g) & $6.97 \pm 0.56^{\mathrm{a}}$ & $7.77 \pm 0.35^{\mathrm{a}}$ & $4.40^{\mathrm{ns}}$ \\
\hline $\begin{array}{l}\text { Total phenolic content } \\
\text { (mg CAE/g d.m.) }\end{array}$ & $10.08 \pm 0.15^{a}$ & $5.71 \pm 0.08^{b}$ & $1982.38^{* * *}$ \\
\hline $\begin{array}{l}\text { Antioxidant capacity } \\
\text { (mg Trolox/g d.m.) }\end{array}$ & $8.67 \pm 0.09^{a}$ & $4.65 \pm 0.05^{b}$ & $4573.70 * * *$ \\
\hline
\end{tabular}

\pm represents standard deviation from three replications of treatments. Different superscripts indicate significantly different means $(p<0.05)$ between HP-assisted and conventionally de-bittered olive spreads, according to Duncan's test $(p<0.05)$. df: 1 , significance levels: ***: $p<0.001$; ns: not significant $(p>0.05)$.

The application of different de-bittering processes did not significantly affect the nutritional characteristics of the final developed spreads. However, the total phenolic content of the spread produced by using the HP-assisted de-bittered olive residue was double compared to the spread produced with the conventionally de-bittered residue. $\mathrm{HP}$ processing as a de-bittering method resulted in an olive residue with higher phenolic content compared to conventionally de-bittered ones due to shorter duration of the debittering process, limiting the oxidative reaction and the degradation of total phenolic compounds of olive residues. This resulted in products of higher antioxidant capacity when the HP-assisted de-bittering procedure of the olive residue was followed.

The final olive-based products had a high content of proteins $(\sim 10 \mathrm{~g} / 100 \mathrm{~g}$ of the product), crude fibers ( $>6 \mathrm{~g} / 100 \mathrm{~g}$ of the product), essential fatty acids (Table 5$)$ and phenolic compounds. 
Table 5. Fatty acids composition of untreated olive paste residue, HP-assisted (200 MPa, $10 \mathrm{~min}, 1: 4$ ratio of sample per solution) and conventionally ( $2 \mathrm{~h}, 1: 4$ ratio of sample per solution) de-bittered olive spreads.

\begin{tabular}{|c|c|c|c|c|}
\hline Fatty Acids Composition (\%) & $\begin{array}{l}\text { Untreated Olive } \\
\text { Paste Residue }\end{array}$ & $\begin{array}{c}\text { Spread Produced by } \\
\text { HP-Assisted de-Bittered } \\
\text { Olive Residue }\end{array}$ & $\begin{array}{c}\text { Spread Produced by } \\
\text { Conventionally } \\
\text { de-Bittered Olive Residue }\end{array}$ & F-Value \\
\hline Myristic acid (C14:0) & $0.094 \pm 0.005^{\mathrm{a}}$ & $0.056 \pm 0.002^{\mathrm{c}}$ & $0.071 \pm 0.003^{b}$ & $86.76^{* * *}$ \\
\hline Palmitic acid (C16:0) & $11.50 \pm 0.09^{\mathrm{a}}$ & $7.48 \pm 0.05^{c}$ & $7.85 \pm 0.04^{b}$ & $3641.80^{* * *}$ \\
\hline Palmitoleic acid (C16:1, cis-9) & $0.623 \pm 0.019^{\mathrm{a}}$ & $0.268 \pm 0.011^{b}$ & $0.273 \pm 0.018^{b}$ & $473.82 * * *$ \\
\hline Stearic acid (C18:0) & $2.89 \pm 0.01^{\mathrm{c}}$ & $3.00 \pm 0.02^{b}$ & $3.14 \pm 0.05^{\mathrm{a}}$ & $47.10 * * *$ \\
\hline Elaidic acid (C18:1, trans-9) & $0.058 \pm 0.019^{b}$ & $0.390 \pm 0.010^{\mathrm{a}}$ & $0.390 \pm 0.015^{\mathrm{a}}$ & $482.03^{* * *}$ \\
\hline Oleic acid (C18:1, cis-9) & $75.10 \pm 0.05^{\mathrm{a}}$ & $67.10 \pm 0.08^{b}$ & $64.70 \pm 0.09^{c}$ & $15699.00^{* * *}$ \\
\hline Linoleic acid (C18:2 cis-9,12), & $4.77 \pm 0.03^{c}$ & $17.90 \pm 0.19^{\mathrm{a}}$ & $17.50 \pm 0.28^{b}$ & $4419.67^{* * *}$ \\
\hline $\begin{array}{c}\alpha \text {-Linolenic acid (C18:3, } \\
\text { cis-9,12,15) }\end{array}$ & $0.491 \pm 0.045^{\mathrm{a}}$ & $0.175 \pm 0.010^{b}$ & $0.172 \pm 0.009^{b}$ & $163.61^{* * *}$ \\
\hline Arachidic acid (C20:0) & $0.491 \pm 0.032^{\mathrm{a}}$ & $0.236 \pm 0.022^{b}$ & $0.212 \pm 0.017^{\mathrm{b}}$ & $140.23 * * *$ \\
\hline cis-11-Eicosenoic acid (C20:1) & $0.265 \pm 0.017^{\mathrm{a}}$ & $0.180 \pm 0.032^{b}$ & $0.186 \pm 0.014^{b}$ & $8.65^{\mathrm{ns}}$ \\
\hline $\begin{array}{l}\text { cis-11,14-Eicosadienoic acid } \\
\text { (C20:2) }\end{array}$ & $0.548 \pm 0.012^{\mathrm{a}}$ & $0.550 \pm 0.010^{a}$ & $0.546 \pm 0.017^{\mathrm{a}}$ & $0.07^{\mathrm{ns}}$ \\
\hline Behenic acid (C22:0) & $0.105 \pm 0.027^{b}$ & $0.160 \pm 0.008^{\mathrm{a}}$ & $0.161 \pm 0.011^{\mathrm{a}}$ & $10.66^{* *}$ \\
\hline Lignoceric acid (C24:0) & $0.063 \pm 0.009^{a}$ & $0.065 \pm 0.012^{\mathrm{a}}$ & $0.073 \pm 0.015^{\mathrm{a}}$ & $0.57^{\mathrm{ns}}$ \\
\hline
\end{tabular}

\pm represents standard deviation from three replications of treatments. Different superscript small letters indicate significantly different means between untreated, HP-assisted and conventionally de-bittered olive paste residues, according to Duncan's test $(p<0.05)$. df: 2 , significance levels: ${ }^{* *}: p<0.001{ }^{* *}: p<0.01$; ns: not significant $(p>0.05)$.

Typically, the spreads that contain nuts also have a small amount of a plant oil that acts as an emulsifier, thus inhibiting the oil separation. This emulsifier-oil could improve the texture properties of the spread and enhance the oxidation reactions during storage. The high protein content was delivered from the ground nuts (hazel, almond, pumpkin and sunflower seeds) that are considered a source of protein and essential amino acids [64]. Approximately $70 \%$ of the total fat was monounsaturated fatty acids, such as oleic acid $(\sim 65-67 \%)$, which was delivered from olive paste residue. Furthermore, $18 \%$ of the total fat was polyunsaturated fatty acids; the linoleic acid (known as omega 6) was the major fatty acid that was delivered mainly from the nuts, as well as the $25 \%$ from the olive paste residue. Therefore, the olive spread has considerable potential to be consumed as a healthy spread. In literature, Özcan and Seven [65] reported that peanut butters from ÇOM and NC-7 cultivars contained a significant amount of oleic (48-55\%), linoleic (26-31\%) and palmitic $(9.3-10.8 \%)$ acid.

\subsection{Shelf-Life Determination}

In order to estimate the shelf-life of both olive spreads, an accelerated experiment was conducted, including the monitoring of quality parameters and sensory evaluation during storage at 20,30 and $40{ }^{\circ} \mathrm{C}$ for $\sim 6$ months. Loads of the total viable count (TVC) and yeasts / molds in the olive spreads were below the detection limit $(<2 \log \mathrm{CFU} / \mathrm{g})$ during storage at all studied temperatures.

The major quality parameter that was used to determine the shelf-life of the novel olive-based spreads was PV value. PV limit was set as $30 \mathrm{meqO}_{2} / \mathrm{kg}$, which indicates the initial stage of fat and oil oxidation in foods. In Table 6, the rate constant of PV of samples at all studied storage conditions for both spreads is presented.

An increase in storage temperature led to increased rate constants of the PV of both spreads, as expected, since the oxidation mechanism is usually slowed down at lower temperatures [66-68]. Spreads produced by HP-assisted de-bittered olive residue exhibited lower values of PV increase rate constants compared to the spread produced by the conventionally de-bittered olive residue $(p<0.05)$; this might be attributed to the higher phenolic content of HP-assisted de-bittered residue providing a protective effect in oxidation reactions. 
Table 6. Rate constants $\mathrm{k}\left(\mathrm{d}^{-1}\right)$ of the PV value increase during storage at $20-40{ }^{\circ} \mathrm{C}$ and shelf-life determination (d) at 4 and $20^{\circ} \mathrm{C}$ of the spreads produced by $\mathrm{HP}$-assisted (200 MPa, $10 \mathrm{~min}, 1: 4$ ratio of sample per solution) and conventionally ( $2 \mathrm{~h}$, 1:4 ratio of sample per solution) de-bittered olive spreads.

\begin{tabular}{ccc}
\hline Storage Temperature $\left({ }^{\circ} \mathbf{C}\right)$ & $\mathbf{k}^{\left(\mathbf{d}^{-\mathbf{1}}\right)}$ & $\begin{array}{c}\text { Spread Produced by Conventionally } \\
\text { de-Bittered Olive Residue }\end{array}$ \\
\cline { 2 - 3 } & $\begin{array}{c}\text { Spread Produced by HP-Assisted } \\
\text { de-Bittered Olive Residue }\end{array}$ & $0.1377 \pm 0.0022^{\mathrm{aB}}$ \\
20 & $0.1234 \pm 0.0012^{\mathrm{aA}}$ & $0.1499 \pm 0.0037^{\mathrm{bB}}$ \\
30 & $0.1406 \pm 0.0026^{\mathrm{bA}}$ & $0.1761 \pm 0.0096^{\mathrm{bB}}$ \\
\hline 40 & $0.1588 \pm 0.0036^{\mathrm{cA}}$ & $275 \pm 12^{\mathrm{B}}$ \\
\hline $4^{\circ} \mathrm{C}$ & Shelf-life determination (days) & $182 \pm 9^{\mathrm{B}}$ \\
\hline $20^{\circ} \mathrm{C}$ & $293 \pm 6^{\mathrm{A}}$ & $215^{\mathrm{A}}$ \\
\hline
\end{tabular}

\pm represents standard error of nonlinear regression analysis of Equations (2) and (3). Different superscript capital letters indicate significantly different means $(p<0.05)$ within a row (differences between de-bittering techniques) and different superscript small letters indicate significantly different means $(p<0.05)$ within a column (differences between storage temperatures).

The changes in free fatty acids of all studied olive spreads at zero time and after 4 months of storage at $40{ }^{\circ} \mathrm{C}$ are presented in Table 7 .

Table 7. Fatty acids profile (SFA, MUFA, PUFA and OS) of spreads produced by HP-assisted (200 MPa, $10 \mathrm{~min}, 1: 4$ ratio of sample per solution) de-bittered olive residue and by conventionally ( $2 \mathrm{~h}, 1: 4$ ratio of sample per solution) de-bittered olive residue, at zero time and after 4 months of storage at $40^{\circ} \mathrm{C}$.

\begin{tabular}{|c|c|c|c|c|c|c|}
\hline \multirow{2}{*}{$\begin{array}{c}\text { Fatty Acids } \\
\text { Composition }(\%)\end{array}$} & \multicolumn{3}{|c|}{$\begin{array}{c}\text { Spread Produced by HP-Assisted de-Bittered } \\
\text { Olive Residue }\end{array}$} & \multicolumn{3}{|c|}{$\begin{array}{c}\text { Spread Produced by Conventionally de-Bittered } \\
\text { Olive Residue }\end{array}$} \\
\hline & 0 Days & $\begin{array}{l}4 \text { Months at } \\
40{ }^{\circ} \mathrm{C}\end{array}$ & F-Value & 0 Days & $\begin{array}{l}4 \text { Months at } \\
40{ }^{\circ} \mathrm{C}\end{array}$ & F-Value \\
\hline SFA (\%) & $10.99 \pm 0.25^{\mathrm{bA}}$ & $12.91 \pm 0.12^{\mathrm{aB}}$ & $143.81^{* * *}$ & $11.51 \pm 0.45^{\mathrm{bA}}$ & $13.80 \pm 0.22^{\mathrm{aA}}$ & $62.70^{* * *}$ \\
\hline MUFA (\%) & $67.93 \pm 1.12^{\mathrm{aA}}$ & $64.75 \pm 0.99 \mathrm{bA}$ & $13.58 *$ & $65.55 \pm 0.82^{\mathrm{aA}}$ & $62.25 \pm 0.35^{\mathrm{bB}}$ & $41.10^{* *}$ \\
\hline PUFA (\%) & $18.62 \pm 0.12^{\mathrm{aA}}$ & $18.60 \pm 0.08^{\mathrm{aA}}$ & $0.1^{\mathrm{ns}}$ & $18.22 \pm 0.17 \mathrm{aB}$ & $17.21 \pm 0.33^{\mathrm{bB}}$ & $22.21^{* *}$ \\
\hline OS (\%) & $890.93 \pm 2.35^{\mathrm{aA}}$ & $887.45 \pm 3.21^{\mathrm{aA}}$ & $2.3^{\mathrm{ns}}$ & $870.25 \pm 1.89^{a B}$ & $821.75 \pm 2.05 \mathrm{bB}$ & $908.10^{* * *}$ \\
\hline \multirow{4}{*}{ F-value for 0 days } & SFA (\%) & $3.06^{\mathrm{ns}}$ & & \multirow{4}{*}{$\begin{array}{c}\text { F-value for } 4 \\
\text { months at } 40^{\circ} \mathrm{C}\end{array}$} & SFA (\%) & $37.84^{* *}$ \\
\hline & MUFA (\%) & $8.82^{\mathrm{ns}}$ & & & MUFA (\%) & $17.01 *$ \\
\hline & PUFA (\%) & 11.09 * & & & PUFA (\%) & $50.27^{* *}$ \\
\hline & OS $(\%)$ & $141.00^{* * *}$ & & & OS $(\%)$ & $892.70^{* * *}$ \\
\hline
\end{tabular}

*SFA: saturated fatty acids; MUFA: monounsaturated fatty acids; PUFA: polyunsaturated fatty acids; OS: oxidative susceptibility $(\mathrm{OS}=\mathrm{MUFA}+45 *$ linoleic acid $+100 *$ linolenic acid $)[69] . \pm$ represents standard deviation from three replications of treatments. Different superscript capital letters indicate significantly different means $(p<0.05)$ within a row (differences between de-bittering techniques) and different superscript small letters indicate significantly different means $(p<0.05)$ within a column (differences between storage temperatures), according to Duncan's test $(p<0.05)$. df: 3 , significance levels: ${ }^{* *}: p<0.001$; $^{* *}: p<0.01 ; *: p<0.05$; ns: not significant $(p>0.05)$.

The obtained results showed that during the accelerated storage at $40{ }^{\circ} \mathrm{C}$, the amount of saturated fatty acids (SFA) was slightly increased, whereas the amount of monounsaturated fatty acids (MUFA) was decreased for all studied olive spreads. These changes in the composition of fatty acids occurred due to the oxidation reactions that took place during storage, causing quality degradation of the final spreads. Nevertheless, it seems that the contained antioxidant compounds, which were delivered from olive oil residues, had a protective effect, resulting in significant oxidative stability. This was also confirmed by the amount of oxidative susceptibility (OS) that has high values even after 4 months of storage at $40{ }^{\circ} \mathrm{C}$ for both olive spreads. Olive paste is a good source of functional compounds-mainly phenolic compounds-and its incorporation in food systems results in final functional products with a health-promoting profile and enhanced oxidative stability. Similar effects have been previously referred to for cookies enriched with olive paste [70]. 
In Figure 3, the scores of sensory evaluation for both olive spreads at zero time and after $93 \mathrm{~d}$ of storage at $20^{\circ} \mathrm{C}$ are presented.
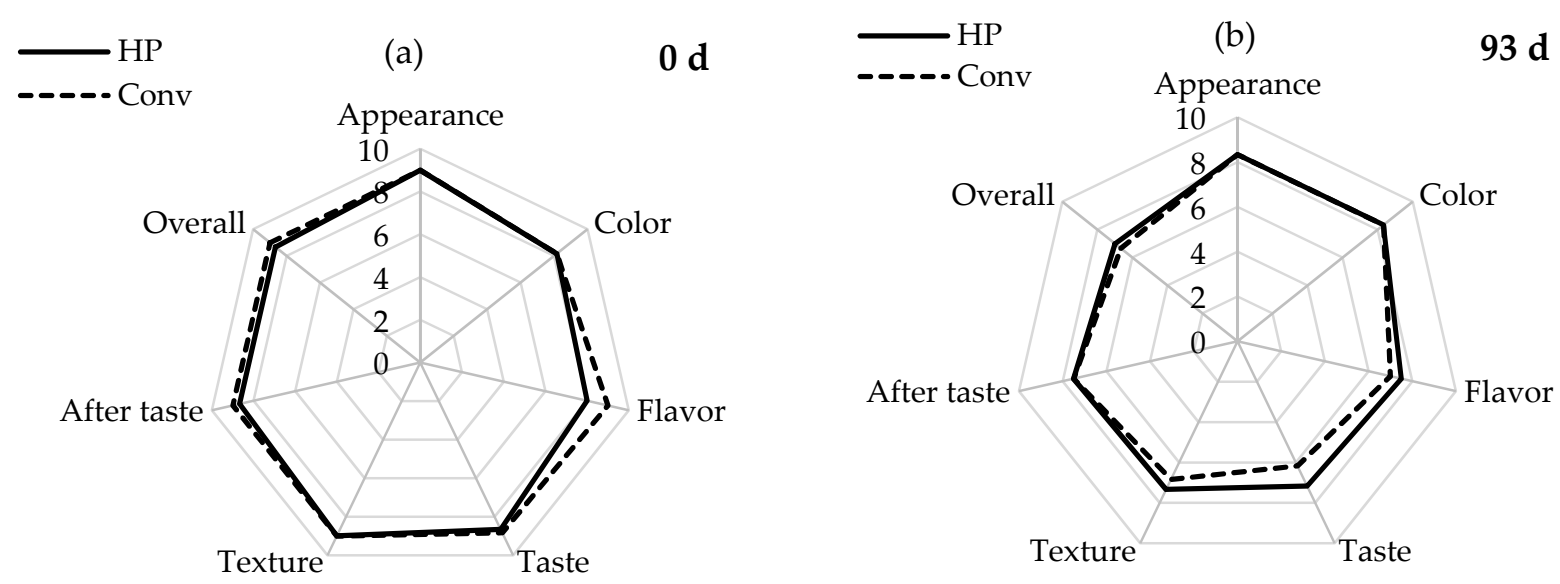

Figure 3. Radar chart of sensory scoring of spreads produced by HP-assisted (200 MPa, $10 \mathrm{~min}, 1: 4$ ratio of sample per solution) de-bittered olive residue ( - ) and by conventionally ( $2 \mathrm{~h}, 1: 4$ ratio of sample per solution) de-bittered olive residue (- - -) at zero time (a) and after 93 days (b) at $20{ }^{\circ} \mathrm{C}$.

At zero time, all organoleptic attributes for both olive spreads had scores above 8 . No differences were observed between organoleptic characteristics for both olive spreads. A slight decrease in flavor score was noticed for HP-assisted de-bittered olive spread compared to conventionally de-bittered ones. This result is in accordance with other studies in literature that have reported that HP treatment can lead to a negative effect in volatile compounds of a food product [71], while at the same time some sensory properties may not be fully retained. During the shelf-life test at $20^{\circ} \mathrm{C}$, it was observed that the deterioration of sensory indices was more pronounced for the conventionally de-bittered olive spread. The scores for flavor and taste during the sensory evaluation of spreads produced by HP-assisted de-bittered olive residue were significantly $(p<0.05)$ higher compared to the spread from the conventionally de-bittered residue after 93 days of storage at room temperature. The shelf-life of the spreads produced by HP-assisted de-bittered olive residue and by conventionally de-bittered olive residue, for storage at $4{ }^{\circ} \mathrm{C}$, was predicted through extrapolation of the linear regression of Equation (3) as 9.5 and 9 months, respectively. Based on US FDA Food Code [72] for the safety assurance of products, the pasteurized food products could be stored at ambient temperature, if their $\mathrm{pH}$ value is lower than 4.60. The respective shelf-life of the new olive spreads at room temperature (since they are safe at room temperatures based on their low $\mathrm{pH}$ value) was also estimated approximately as 6 and 7 months for conventionally and HP-assisted de-bittered products, respectively.

\section{Conclusions}

The performed experiments and the obtained results indicate that the patented cold pressing technique significantly improved the yield and quality of olive oil (total olive oil yield from the cold-pressed olives equal to $15.0 \pm 0.3 \%$, leading to a $32 \%$ decrease compared to traditional olive oil production). The olive paste residue resulting from the oil separation after the centrifugation step had a residual oil content of approximately $0.7 \mathrm{~g}$ oil $/ \mathrm{g} \mathrm{d} . \mathrm{m}$. and a high phenolic content equal to $18.45 \mathrm{mg} \mathrm{CAE} / \mathrm{g} \mathrm{d.m.,} \mathrm{making} \mathrm{it} \mathrm{suitable} \mathrm{for} \mathrm{reuse}$ and incorporation in a new product, since all unsuitable substances, such as pits, residual leaves and olive skin, had already been removed from the cold press machine. In the traditional extraction process, the resulting olive oil residue is unsuitable for further reuse in food systems. The scale-up of the batch processed using the patented cold pressing machine will be a challenge for the olive oil production industry. 
High-pressure technology was efficiently used for the de-bittering process of the olive residue. Oleuropein content decreased by up to $30 \%$ after $1 \mathrm{~h}$ of conventional debittering. On the other hand, HP-assisted treatment for only 10 min resulted in 50\% decrease of oleuropein content compared to the concentration of untreated paste. HP treatment significantly reduced the intensity of the bitter taste of olive paste as evidenced by organoleptic analysis of the final products. A ratio of sample per solution 1:4 and debittering time $2 \mathrm{~h}$ and $10 \mathrm{~min}$ were selected as the optimal conditions for conventional and $\mathrm{HP}$-assisted (200 MPa) de-bittering processes, respectively. Under these conditions, both de-bittered olive paste residues exhibited adequate oleuropein content reduction by up to $50 \%$. This statement could also be applied in the production of table olives insofar as the de-bittering process is time-consuming and demands chemicals that have environmental impact.

After the conventional and HP-assisted de-bittering process, the olive paste residue was incorporated in an innovative, high-added-value, healthy olive-based spread, along with other functional ingredients such as honey and ground nuts. The results showed that the proposed olive spread product had a texture similar to peanut butter. The final olive-based products had a high content of protein $(\sim 10 \mathrm{~g} / 100 \mathrm{~g}$ of the product), crude fibers ( $>6 \mathrm{~g} / 100 \mathrm{~g}$ of the product), essential fatty acids and phenolic compounds. The shelf-life of the spread produced by HP-assisted de-bittered olive residue for storage at $4{ }^{\circ} \mathrm{C}$ was estimated as 9.5. The health-promoting profile of the olive oil production residue also has to be validated through clinical tests either as a stand-alone product or as an ingredient in new/innovative food products.

In parallel to the production of a healthy spread, the valorization of olive paste residue significantly affects (reduces) the environmental impact of olive oil production, minimizing the most important olive oil production issue.

Author Contributions: Conceptualization, G.K.; data curation, P.S.; formal analysis, V.A., S.C.; investigation, V.A., S.C., G.K.; methodology, V.A., S.C.; project administration, G.K.; resources, G.K.; software, V.A., S.C., P.S.; supervision, G.K.; validation, P.S.; visualization, V.A., S.C.; writing—original draft, V.A.; writing — review and editing, S.C., G.K. All authors have read and agreed to the published version of the manuscript.

Funding: This research received no external funding.

Institutional Review Board Statement: Not applicable.

Informed Consent Statement: Not applicable.

Data Availability Statement: The datasets generated during the current study are available from the corresponding author on reasonable request.

Acknowledgments: The authors would like to thank Stylianos Tzanakakis for kindly supplying his patented High-Pressure Semi-Automatic Hydraulic System, integrating the invented "Hydraulic Direct Cold Press Method", which was developed in his company PETROKOLYMPOS IKE.

Conflicts of Interest: The authors declare no conflict of interest.

\section{References}

1. Tsarouhas, P.; Achillas, C.; Aidonis, D.; Folinas, D.; Maslis, V. Life Cycle Assessment of olive oil production in Greece. J. Clean. Prod. 2015, 93, 75-83. [CrossRef]

2. Anania, G.; Pulpo, M.R. Olive oil in the Mediterranean area production. Consumption and trade. Obs. CIHEAM 2011, 16, 1-26.

3. Bedbabis, S.; Trigui, D.; Ben Ahmed, C.; Clodoveo, M.L.; Camposeo, S.; Vivaldi, G.A.; Ben Rouina, B. Long-terms effects of irrigation with treated municipal wastewater on soil, yield and olive oil quality. Agric. Water Manag. 2015, 160, 14-21. [CrossRef]

4. Turkekul, B.; Gunden, C.; Abay, C.; Miran, B. A Market Share Analysis of Virgin Olive Oil Producer Countries with Special Respect to Competitiveness; European Association of Agricultural Economists: Barcelona, Spain, 2007; No. 688-2016-47166.

5. Servili, M.; Taticchi, A.; Esposto, S.; Sordini, B.; Urbani, B.S.A.S. Technological Aspects of Olive Oil Production. In Olive Germplasm-The Olive Cultivation, Table Olive and Olive Oil Industry in Italy; InTech: Rijeka, Croatia, 2012; pp. 151-172.

6. Ranalli, A.; Costantini, N.; De Mattia, G.; Ferrante, M.L. Evaluating two kinds of centrifuged virgin oils arising from continuous olive processing. J. Sci. Food Agric. 2000, 80, 673-683. [CrossRef] 
7. Clodoveo, M.L. Malaxation: Influence on virgin olive oil quality. Past, present and future-An overview. Trends Food Sci. Technol. 2012, 25, 13-23. [CrossRef]

8. Vlyssides, A.; Loizides, M.; Karlis, P. Integrated strategic approach for reusing olive oil extraction by-products. J. Clean. Prod. 2004, 12, 603-611. [CrossRef]

9. Chanioti, S.; Tzia, C. Optimization of ultrasound-assisted extraction of oil from olive pomace using response surface technology: Oil recovery, unsaponifiable matter, total phenol content and antioxidant activity. LWT 2017, 79, 178-189. [CrossRef]

10. Alburquerque, J.A.; Gonzálvez, J.; Garcia, D.; Cegarra, J. Agrochemical characterisation of "alperujo", a solid by-product of the two-phase centrifugation method for olive oil extraction. Bioresour. Technol. 2004, 91, 195-200. [CrossRef]

11. Ranalli, A.; Lucera, L.; Contento, S. Antioxidizing Potency of Phenol Compounds in Olive Oil Mill Wastewater. J. Agric. Food Chem. 2003, 51, 7636-7641. [CrossRef]

12. Chanioti, S.; Tzia, C. Extraction of phenolic compounds from olive pomace by using natural deep eutectic solvents and innovative extraction techniques. Innov. Food Sci. Emerg. Technol. 2018, 48, 228-239. [CrossRef]

13. Araújo, M.; Pimentel, F.B.; Alves, R.C.; Oliveira, M.B.P. Phenolic compounds from olive mill wastes: Health effects, analytical approach and application as food antioxidants. Trends Food Sci. Technol. 2015, 45, 200-211. [CrossRef]

14. Fernández-Bolaños, J.; Rodríguez, G.; Rodríguez, R.; Heredia, A.; Guillén, R.; Jiménez, A. Production in large quan-tities of highly purified hydroxytyrosol from liquid-solid waste of two-phase olive oil processing or "Alperujo". J. Agric. Food Chem. 2002, 50, 6804-6811. [CrossRef] [PubMed]

15. Zbakh, H.; El Abbassi, A. Potential use of olive mill wastewater in the preparation of functional beverages: A review. J. Funct. Foods 2012, 4, 53-65. [CrossRef]

16. Andreou, V.; Psarianos, M.; Dimopoulos, G.; Tsimogiannis, D.; Taoukis, P. Effect of pulsed electric fields and high pressure on improved recovery of high-added-value compounds from olive pomace. J. Food Sci. 2020, 85, 1500-1512. [CrossRef] [PubMed]

17. Lapornik, B.; Prošek, M.; Wondra, A.G. Comparison of extracts prepared from plant by-products using different solvents and extraction time. J. Food Eng. 2005, 71, 214-222. [CrossRef]

18. Roselló-Soto, E.; Koubaa, M.; Moubarik, A.; Lopes, R.P.; Saraiva, J.A.; Boussetta, N.; Grimi, N.; Barba, F.J. Emerging oppor-tunities for the effective valorization of wastes and by-products generated during olive oil production process: Non-conventional methods for the recovery of high-added value compounds. Trends Food Sci. Technol. 2015, 45, 296-310. [CrossRef]

19. Moral, P.S.; Ruiz-Méndez, M.V. Production of pomace olive oil. Grasas y Aceites 2006, 57, 47-55. [CrossRef]

20. Lanza, B.; Di Serio, M.G.; Iannucci, E.; Russi, F.; Marfisi, P. Nutritional, textural and sensorial characterisation of Italian table olives (Olea europaea L. cv. 'Intosso d'Abruzzo'). Int. J. Food Sci. Technol. 2009, 45, 67-74. [CrossRef]

21. Bianchi, G. Lipids and phenols in table olives. Eur. J. Lipid Sci. Technol. 2003, 105, 229-242. [CrossRef]

22. Ramirez, E.; García-García, P.; de Castro, A.; Romero, C.; Brenes, M. Debittering of black dry-salted olives. Eur. J. Lipid Sci. Technol. 2013, 115, 1319-1324. [CrossRef]

23. Tamer, C.E.; Incedayı, B.; Yıldız, B.; Çopur, Ö.U. The Use of Vacuum Impregnation for Debittering Green Olives. Food Bioprocess Technol. 2013, 6, 3604-3612. [CrossRef]

24. Owen, R.; Haubner, R.; Hull, W.; Erben, G.; Spiegelhalder, B.; Bartsch, H.; Haber, B. Isolation and structure elucidation of the major individual polyphenols in carob fibre. Food Chem. Toxicol. 2003, 41, 1727-1738. [CrossRef]

25. Shouqin, Z.; Jun, X.; Changzheng, W. High hydrostatic pressure extraction of flavonoids from propolis. J. Chem. Technol. Biotechnol. 2005, 80, 50-54. [CrossRef]

26. Zhang, S.; Zhu, J.; Wang, C. Novel high pressure extraction technology. Int. J. Pharm. 2004, 78, 471-474.

27. Chanioti, S.; Andreou, V.; Stergiou, P.; Katsaros, G. Development of a high added-value healthy spread by valorizing olive oil production residue. In Proceedings of the RETASTE Conference Abstracts Vol. 1 RETASTE-VAL-117, Athens, Greece, 6-8 May 2021.

28. Andreou, V.; Dimopoulos, G.; Alexandrakis, Z.; Katsaros, G.; Oikonomou, D.; Toepfl, S.; Heinz, V.; Taoukis, P. Shelf-life evaluation of virgin olive oil extracted from olives subjected to nonthermal pretreatments for yield increase. Innov. Food Sci. Emerg. Technol. 2017, 40, 52-57. [CrossRef]

29. Henneberg, W.; Stohmann, F. Fiber das Erhaltungsfutter volljahrigen Rindviehs.1. Landwirtsch 1859, 3, 485-551.

30. Khanizadeh, S.; Buszard, D.; Zarkadas, C.G. Misuse of the Kjeldahl Method for Estimating Protein Content in Plant Tissue. HortScience 1995, 30, 1341-1342. [CrossRef]

31. Andreou, V.; Dimopoulos, G.; Tsonas, T.; Katsimichas, A.; Limnaios, A.; Katsaros, G.; Taoukis, P. Pulsed Electric Fields-Assisted Drying and Frying of Fresh Zucchini. Food Bioprocess Technol. 2021, 14, 2091-2106. [CrossRef]

32. Segura, M.E.M.; Rosell, C.M. Chemical Composition and Starch Digestibility of Different Gluten-free Breads. Plant Foods Hum. Nutr. 2011, 66, 224-230. [CrossRef] [PubMed]

33. McDermid, K.J.; Stuercke, B. Nutritional composition of edible Hawaiian seaweeds. Environ. Boil. Fishes 2003, 15, 513-524. [CrossRef]

34. Official Methods of Analysis, 16th ed.; AOAC INTERNATIONAL: Arlington, VA, USA, 1995.

35. Waterhouse, A.L. Determination of total phenolics. Curr. Protoc. Food Anal. Chem. 2002, 6, I1.1.1-I1.1.8.

36. Brand-Williams, W.; Cuvelier, M.E.; Berset, C. Use of a free radical method to evaluate antioxidant activity. LWT Food Sci. Technol. 1995, 28, 25-30. [CrossRef] 
37. Aka-Kayguluoglu, A.; Akpinar-Bayizit, A.; Sahin-Cebeci, O.I. Evaluation of physicochemical and sensory properties of green olive pastes. Res. J. 2014, 13, 654-658.

38. Marx, I.; Rodrigues, N.; Dias, L.; Veloso, A.C.A.; Pereira, J.A.; Drunkler, D.A.; Peres, A.M. Sensory classification of table olives using an electronic tongue: Analysis of aqueous pastes and brines. Talanta 2017, 162, 98-106. [CrossRef] [PubMed]

39. Bendini, A.; Valli, E.; Barbieri, S.; Toschi, T.G. Sensory analysis of virgin olive oil. In Olive Oil—Constituents, Quality, Health Properties and Bioconversions; InTech: Rijeka, Croatia, 2012; pp. 109-130.

40. Conte, P.; Fadda, C.; Del Caro, A.; Urgeghe, P.P.; Piga, A. Table Olives: An Overview on Effects of Processing on Nutritional and Sensory Quality. Foods 2020, 9, 514. [CrossRef] [PubMed]

41. Farhoosh, R.; Hoseini-Yazdi, S.-Z. Shelf-life prediction of olive oils using empirical models developed at low and high temperatures. Food Chem. 2013, 141, 557-565. [CrossRef]

42. Okpala, C.O.R.; Bono, G.; Geraci, M.L.; Sardo, G.; Vitale, S.; Schaschke, C.J. Lipid oxidation kinetics of ozone-processed shrimp during iced storage using peroxide value measurements. Food Biosci. 2016, 16, 5-10. [CrossRef]

43. Gotoh, N.; Wada, S. The importance of peroxide value in assessing food quality and food safety. J. Am. Oil Chem. Soc. 2006, 83, 473-474. [CrossRef]

44. Inarejos-García, A.M.; Gómez-Rico, A.; Salvador, M.D.; Fregapane, G. Influence of malaxation conditions on virgin olive oil yield, overall quality and composition. Eur. Food Res. Technol. 2009, 228, 671-677. [CrossRef]

45. Ranalli, A. Aspects and problems connected with the storage and the preservation of the olive-oil. Inf. Agrar. 1988, 44, 79-85.

46. Ranalli, A.; Pollastri, L.; Contento, S.; Iannucci, E.; Lucera, L. Effect of olive paste kneading process time on the overall quality of virgin olive oil. Eur. J. Lipid Sci. Technol. 2003, 105, 57-67. [CrossRef]

47. Di Giovacchino, L.; Costantini, N.; Serraiocco, A.; Surricchio, G.; Basti, C. Natural antioxidants and volatile com-pounds of virgin olive oils obtained by two or three-phases centrifugal decanters. Eur. J. Lipid Sci. Technol. 2001, 103, 279-285. [CrossRef]

48. Caponio, F.; Alloggio, V.; Gomes, T. Phenolic compounds of virgin olive oil: Influence of paste preparation tech-niques. Food Chem. 1999, 64, 203-209. [CrossRef]

49. Di Giovacchino, L.; Sestili, S.; Di Vincenzo, D. Influence of olive processing on virgin olive oil quality. Eur. J. Lipid Sci. Technol. 2002, 104, 587-601. [CrossRef]

50. Catalano, P.; Caponio, F. Machines for olive paste preparation producing quality virgin olive oil. Lipid Fett 1996, 98, 408-412. [CrossRef]

51. Caponio, F.; Catalano, P. Hammer crushers vs disk crushers: The influence of working temperature on the quality and preservation of virgin olive oil. Eur. Food Res. Technol. 2001, 213, 219-224. [CrossRef]

52. Amirante, P.; Clodoveo, M.L.; Tamborrino, A.; Leone, A.; Paice, A.G. Influence of the crushing system: Phenol content in virgin olive oil produced from whole and de-stoned pastes. In Olives and Olive Oil in Health and Disease Prevention; Academic Press: Cambridge, MA, USA, 2010; pp. 69-76.

53. Nunes, M.A.; Costa, A.S.; Bessada, S.; Santos, J.; Puga, H.; Alves, R.C.; Freitas, V.; Oliveira, M.B.P. Olive pomace as a valuable source of bioactive compounds: A study regarding its lipid-and water-soluble components. Sci. Total Environ. 2018, 644, 229-236. [CrossRef] [PubMed]

54. Zabaniotou, A.; Kalogiannis, G.; Kappas, E.; Karabelas, A. Olive residues (cuttings and kernels) rapid pyrolysis product yields and kinetics. Biomass Bioenergy 2000, 18, 411-420. [CrossRef]

55. Cocolin, L.; Alessandria, V.; Botta, C.; Gorra, R.; De Filippis, F.; Ercolini, D.; Rantsiou, K. NaOH debittering induces changes in bacterial ecology during table olives fermentation. PLoS ONE 2013, 8, e69074. [CrossRef] [PubMed]

56. Brenes, M.; de Castro, A. Transformation of oleuropein and its hydrolysis products during Spanish-style green olive processing. J. Sci. Food Agric. 1998, 77, 353-358. [CrossRef]

57. Charoenprasert, S.; Mitchell, A. Factors Influencing Phenolic Compounds in Table Olives (Olea europaea). J. Agric. Food Chem. 2012, 60, 7081-7095. [CrossRef] [PubMed]

58. Habibi, M.; Golmakani, M.T.; Mesbahi, G.; Majzoobi, M.; Farahnaky, A. Ultrasound-accelerated debittering of olive fruits. Innov. Food Sci. Emerg. Technol. 2015, 31, 105-115. [CrossRef]

59. Habibi, M.; Golmakani, M.T.; Farahnaky, A.; Mesbahi, G.; Majzoobi, M. NaOH-free debittering of table olives using power ultrasound. Food Chem. 2016, 192, 775-781. [CrossRef]

60. García, A.; Romero, C.; Medina, E.; García, P.; De Castro, A.; Brenes, M. Debittering of olives by polyphenol oxidation. J. Agric. Food Chem. 2008, 56, 11862-11867. [CrossRef] [PubMed]

61. Servili, M.; Settanni, L.; Veneziani, G.; Esposto, S.; Massitti, O.; Taticchi, A.; Urbani, S.; Montedoro, G.F.; Corsetti, A. The Use of Lactobacillus pentosus $1 \mathrm{MO}$ To Shorten the Debittering Process Time of Black Table Olives (Cv. Itrana and Leccino): A Pilot-Scale Application. J. Agric. Food Chem. 2006, 54, 3869-3875. [CrossRef]

62. Muego, K.F.; Resurreccion, A.V.A.; Hung, Y. Characterization of the textural properties of spreadable peanut based products. J. Texture Stud. 1990, 21, 61-74. [CrossRef]

63. Ahmed, E.M.; Ali, T. Textural Quality of Peanut Butter as Influenced by Peanut Seed and Oil Contents1. Peanut Sci. 1986, 13, 18-20. [CrossRef]

64. King, J.C.; Blumberg, J.; Ingwersen, L.; Jenab, M.; Tucker, K.L. Tree Nuts and Peanuts as Components of a Healthy Diet. J. Nutr. 2008, 138, 1736S-1740S. [CrossRef] [PubMed] 
65. Özcan, M.; Seven, S. Physıcal and chemical analysıs and fatty acıd composition of peanut, peanut oil and peanut butter from ÇOM and NC-7 cultıvars. Grasas y Aceites 2003, 54, 12-18.

66. Labuza, T.P. Shelf-Life Dating of Foods; Food \& Nutrition Press, Inc.: Westport, CT, USA, 1982.

67. Chu, Y.-H.; Hsu, H.-F. Effects of antioxidants on peanut oil stability. Food Chem. 1999, 66, 29-34. [CrossRef]

68. García-Pascual, P.; Mateos, M.; Carbonell, V.; Salazar, D. Influence of Storage Conditions on the Quality of Shelled and Roasted Almonds. Biosyst. Eng. 2003, 84, 201-209. [CrossRef]

69. Cert, A.; Alba, J.; León-Camacho, M.; Moreda, W.; Pérez-Camino, M.C. Effects of Talc Addition and Operating Mode on the Quality and Oxidative Stability of Virgin Olive Oils Obtained by Centrifugation. J. Agric. Food Chem. 1996, 44, 3930-3934. [CrossRef]

70. Argyri, E.A.; Piromalis, S.P.; Koutelidakis, A.; Kafetzopoulos, D.; Petsas, A.S.; Skalkos, D.; Karantonis, H.C. Ol-ive Paste-Enriched Cookies Exert Increased Antioxidant Activities. Appl. Sci. 2021, 11, 5515. [CrossRef]

71. Oey, I.; Lille, M.; Van Loey, A.; Hendrickx, M. Effect of high-pressure processing on colour, texture and flavour of fruit- and vegetable-based food products: A review. Trends Food Sci. Technol. 2008, 19, 320-328. [CrossRef]

72. Food Code. Recommendations of the United States Public Health Service; National Technical Information Service Publication, PB2005-102200; Food and Drug Administration: New Orleans, LA, USA, 2005. 